Optical Property Enhancement and Durability Evaluation of Heat Receiver Aperture Shield Materials

Kim K. de Groh and Donald A. Jaworske

Lewis Research Center, Cleveland, Ohio

Daniela C. Smith

Cleveland State University, Cleveland, Ohio

Prepared for the

36th Aerospace Sciences Meeting \& Exhibit

sponsored by the American Institute of Aeronautics and Astronautics

Reno, Nevada, January 12-15, 1998

National Aeronautics and

Space Administration

Lewis Research Center 


\section{Acknowledgments}

The authors would like to thank Tim McCollum of Cleveland State University for writing the Emitcalc program for thermal emittance calculations, Karen Eubank of AlliedSignal Aerospace for grit-blasting samples, and Eric Golliher and Tom Kerslake of NASA LeRC and Hal Strumpf of AlliedSignal Aerospace for their support of the test program.

Available from

NASA Center for Aerospace Information 800 Elkridge Landing Road

Linthicum Heights, MD 21090-2934

Price Code: A03
National Technical Information Service 5287 Port Royal Road Springfield, VA 22100 Price Code: A03 


\title{
OPTICAL PROPERTY ENHANCEMENT AND DURABILITY EVALUATION OF HEAT RECEIVER APERTURE SHIELD MATERIALS
}

\author{
Kim K. de Groh, Donald A. Jaworske \\ National Aeronautics and Space Administration \\ Lewis Research Center \\ Cleveland, Ohio 44135 \\ and \\ Daniela C. Smith \\ Cleveland State University \\ Cleveland, Ohio 44115
}

Solar Dynamic (SD) power systems have been investigated by the National Aeronautics and Space Administration (NASA) for electrical power generation in space. As part of the International Space Station (ISS) program, NASA Lewis Research Center (LeRC) teamed with the Russian Space Agency (RSA) to build a SD system to be flown on the Russian Space Station MIR. Under the US/Russian SD Flight Demonstration (SDFD) program, LeRC worked with AlliedSignal Aerospace, the heat receiver contractor, on the development, characterization and durability testing of materials to obtain appropriate optical and thermal properties for the SDFD heat receiver aperture shield. The aperture shield is composed of refractory metal multifoil insulation (MFI) attached to an aperture back plate. Because of anticipated off-pointing periods, the aperture shield was designed to withstand the extreme temperatures that $80 \mathrm{~W} / \mathrm{cm}^{2}$ would produce. To minimize the temperature that the aperture shield will reach during off-pointing, it was desired for the aperture shield exterior layer to have a solar absorptance $\left(\alpha_{s}\right)$ to thermal emittance $(\varepsilon)$ ratio as small as possible. In addition, a very low specular reflectance $\left(\rho_{s}<0.1\right)$ was also necessary, because reflected concentrated sunlight could cause overheating of the concentrator which is undesirable.

Testing was conducted at LeRC to evaluate pristine and optical property enhanced molybdenum and tungsten foils and screen covered foils. Molybdenum and tungsten foils were grit-blasted using silicon carbide or alumina grit under various grit-blasting conditions for optical property enhancement. Black rhenium coated tungsten foil was also evaluated. Tungsten, black rhenium-coated tungsten, and grit-blasted tungsten screens of various mesh sizes were placed over the pristine and grit-blasted foils for optical property characterization. Grit-blasting was found to be effective in decreasing the specular reflectance and absorptance/emittance ratio of the refractory foils. The placement of a screen further enhanced these optical properties, with a grit-blasted screen over a grit-blasted foil producing the best results. Based on the optical property enhancement results, samples were tested for atomic oxygen (AO) and vacuum heat treatment (VHT) durability. Grit-blasted ( $\mathrm{Al}_{2} \mathrm{O}_{3}$ grit) $2 \mathrm{mil}$ tungsten foil was chosen for the exterior layer of the SDFD heat receiver aperture shield. A 0.007 in. diameter, $20 \times 20$ mesh tungsten screen was chosen to cover the tungsten foil. Based on these test results, a heat receiver aperture shield test unit has been built by Aerospace Design and Development (A.D.D.) with the screen covered grit-blast tungsten foil exterior layers. The aperture shield was tested in LeRC's Solar Dynamic Ground Test Demonstration (SDGTD) system to verify the thermal and structural durability of the outer foil layers during an offpointing period.

\section{Introduction}

Solar Dynamic power systems have been investigated by NASA for electrical power generation in space. In a SD power system, a solar concentrator reflects or refracts solar energy into the receiver of a heat engine. In the NASA developed heat engine, reflected solar energy is transferred to a Xe-He gaseous working fluid in a closed-

"Copyright (1) 1998 by the American Institute of Aeronautics and Astronautics, Inc. No copyright is asserted in the United States under Title 17, U.S. Code. The U.S. Government has a royalty-free license to exercise all rights under the copyright claimed herein for Governmental Purposes. All other rights are reserved by the copyright owner." 
Brayton cycle heat engine through thermal energy storage (TES) containment canisters (Strumpf, 1994). The heated gas drives a turbo-alternator to produce electric power. The TES canisters contain $\mathrm{LiF}-\mathrm{CaF}_{2}$ eutectic salt, and uses the heat of fusion of the TES material to provide heat for power generation during the eclipse portion of the orbit. A $2 \mathrm{~kW}$ SDGTD system has been developed and built by NASA LeRC (Shaltens, 1995, 1996). The SDGTD system has demonstrated the feasibility of solar dynamic power generation during simulated sun and eclipse cycles in LeRC's large thermal/vacuum space facility (Shaltens 1996). With the completion of the SDGTD system, NASA LeRC started development work on a SD Flight Demonstration (SDFD) program. This program was originally a joint effort with RSA to build a SD system to be tested on the Russian Space Station MIR. Unfortunately, due to budget constraints and MIR logistics, the SDFD program was demanifested in 1996. However, under the SDFD program, AlliedSignal Aerospace designed and qualification tested, in large part, the flight heat receiver. Figure 1 shows a sketch of the SDFD receiver. NASA LeRC was requested to help AlliedSignal Aerospace with the development, characterization, and durability testing of materials to obtain appropriate optical and thermal properties for the SDFD heat receiver aperture shield.

The aperture shield for the SDFD heat receiver serves three functions: to keep heat inside the receiver cavity, to provide structural stiffness for the receiver during launch, and to protect the receiver structure during periods of offpointing. The SDFD aperture shield is composed of refractory metal multifoil insulation (MFI) attached to an aperture back plate (see Fig. 2) (Strumpf 97). This design was chosen because it is structurally superior to the brittle graphite aperture shield used in the SDGTD system (Strumpf 97). The interior of the heat receiver will reach approximately $1,100 \mathrm{~K}$ during normal operating conditions. During periods of off-pointing, a portion of the aperture shield will be exposed to an incident solar flux of $80 \mathrm{~W} / \mathrm{cm}^{2}$ (Kerslake 97). Because of this off-pointing condition, the aperture shield was designed to withstand the extreme temperatures that $80 \mathrm{~W} / \mathrm{cm}^{2}$ will induce. To minimize the temperature that the aperture shield will reach during off-pointing, it was desired for the aperture shield exterior layer to have a solar absorptance $\left(\alpha_{s}\right)$ to thermal emittance $(\varepsilon)$ ratio as small as possible. In addition, a very low specular reflectance $\left(\rho_{s}<0.1\right)$ was necessary, because reflected concentrated sunlight could cause overheating of the concentrator which is undesirable. Decreasing $\rho_{\mathrm{s}}$ would drive the $\alpha_{\mathrm{s}}$ up, therefore an $\alpha_{\mathrm{s}} / \varepsilon$ ratio goal of 1 was chosen.
Tests were conducted at LeRC to evaluate pristine and optical property enhanced refractory metal foils. Foils were grit-blast with different grit and various grit-blasting conditions for optical property enhancement. A screen was chosen as the outer most layer of the aperture shield to support the attachment wires which tie the MFI together (see Fig. 2) (Strumpf 97). Therefore pristine and grit-blast screens of various diameters and mesh sizes were placed over the foils for optical property characterization. Based on the optical properties, several foil and screen samples were tested for AO and high temperature VHT durability. It is necessary that the optical properties are maintained during $\mathrm{AO}$ exposure and under the expected high temperature load during off-pointing in space. Previous research has provided evidence of optical property degradation of grit-blast metals with high temperature vacuum exposure (de Groh 1992, de Groh 1994, Touloukian 70). Atomic oxygen, which is formed by photodissociation of molecular oxygen by ultraviolet radiation, is the predominant species at LEO altitudes. At orbital velocities, spacecraft surfaces are impacted by energetic $\mathrm{AO}(\approx 4.5 \mathrm{eV})$ and are susceptible to $\mathrm{AO}$ degradation. Solar dynamic systems receive sweeping AO impact, because of their solar facing orbits. Although the aperture shield itself will be shielded from most direct AO attack, AO will scatter off the solar concentrator's exterior surface $\left(\mathrm{SiO}_{2}\right)$ and impact the aperture shield. This paper describes the optical property characterization, optical property enhancement, and durability testing of refractory metals for the SDFD aperture shield.

\section{Materials and Experimental Procedures}

\section{Materials}

Molybdenum foil $(0.001$ in. $(0.025 \mathrm{~mm})$ thick) and tungsten foils $(0.001$ in. $(0.025 \mathrm{~mm})$ and 0.002 in. $(0.051 \mathrm{~mm})$ thick) were evaluated for optical properties as-received and after grit-blasting. These refractory metals were chosen because of their high temperature properties (Mo m.p. $2623{ }^{\circ} \mathrm{C}$, W m.p. $3422^{\circ} \mathrm{C}$ ). Tungsten screens were placed over the foils for optical property characterization because of their structural need. Screens of various sizes $(0.01 \mathrm{in} .(0.254 \mathrm{~mm}))$ wire diameter $10 \times 10$ mesh $(10 \times 10$ openings/in. $), 0.007$ in. $(0.178 \mathrm{~mm})$ wire diameter $20 \times 20$ mesh, 0.004 in. $(0.102 \mathrm{~mm})$ wire diameter $30 \times 30$ mesh, 0.003 in. $(0.076 \mathrm{~mm})$ wire diameter $35 \times 35$ mesh, 0.003 in. $(0.076 \mathrm{~mm})$ wire diameter $40 \times 40$ mesh and 0.002 in. $(0.051 \mathrm{~mm})$ wire diameter 50 $\times 50$ mesh) were characterized over various foils. Black Rhenium (Re) coated 0.001 in. $(0.025 \mathrm{~mm})$ thick $W$ foil and Black Re coated 0.010 in. (0.254 mm) wire diameter 
$10 \times 10$ mesh W screen was also evaluated because of their excellent optical properties.

\section{Optical Property Enhancement}

Molybdenum and tungsten foils were grit-blasted using silicon carbide or alumina grit under various pressures and distances for optical property enhancement. SiC gritblasting was done at $70 \mathrm{psi}$, while the pressure was varied from 35 to 50 psi for the $\mathrm{Al}_{2} \mathrm{O}_{3}$ grit. The distance from the grit-blasting nozzle to the sample varied from 3 to $10 \mathrm{in}$. and $<1$ to $8 \mathrm{in}$. for the $\mathrm{SiC}$ and $\mathrm{Al}_{2} \mathrm{O}_{3}$, respectively. Pristine and grit-blast $\mathrm{W}$ screens of various wire diameters and mesh sizes were evaluated over the foil samples to check for the best foil and screen combinations. Screens were grit blast with either $\mathrm{SiC}$ grit ( 70 psi, 1 in.) or $\mathrm{Al}_{2} \mathrm{O}_{3}$ grit ( 45 to $50 \mathrm{psi},<1-1$ in.). Foils and screens were grit-blast at AlliedSignal Aerospace under a certain set of conditions until they developed a uniform texture. Black rheniumcoated $W$ foil ( 0.001 in. thick) and $W$ screen $(10 \times 10$ mesh, $0.01 \mathrm{in}$. wire diameter) was also evaluated for optical properties.

\section{Optical Properties}

Solar integrated total $\left(\rho_{t}\right)$, diffuse $\left(\rho_{d}\right)$ and specular reflectance $\left(\rho_{\mathrm{s}}\right)$, solar absorptance $\left(\alpha_{\mathrm{s}}\right)$, and thermal emittance at $1900^{\circ} \mathrm{C}\left(\varepsilon_{1900}{ }^{\circ} \mathrm{C}\right)$ and at $2600^{\circ} \mathrm{C}\left(\varepsilon_{2600}{ }^{\circ} \mathrm{C}\right)$ were obtained for all samples. Spectral reflectance was obtained using a Perkin-Elmer $\lambda-9$ Spectrophotometer operated with a $150 \mathrm{~mm}$ integrating sphere. Spectral reflectance uncertainty is \pm 2 percent, while repeatability \pm 0.5 percent. Total and diffuse reflectance was obtained from 250 to $2500 \mathrm{~nm}$, and the data were convoluted into the air mass zero solar spectrum to obtain solar integrated values. Specular reflectance was obtained by subtracting $\rho_{\mathrm{d}}$ from $\rho_{\mathrm{t}}$. Solar absorptance was calculated by subtracting $\rho_{t}$ from 1 because the samples are opaque $\left(1-\rho_{t}=\alpha_{s}\right)$. Thermal emittance was calculated by integrating the spectral reflectance data $\left(1-\rho_{\mathrm{t}, \lambda}=\alpha_{\lambda}=\varepsilon_{\lambda}\right)$ into blackbody curves at 1900 and $2600^{\circ} \mathrm{C}$. This was accomplished by first extrapolating the data to higher wavelengths in order to encompass 95 percent of the blackbody spectrum at the desired temperature. A LeRC written program, Emitcalc, was used to extrapolate the data to the appropriate wavelength (5749 $\mathrm{nm}$ for $1900{ }^{\circ} \mathrm{C}$, and $4349 \mathrm{~nm}$ for $2600^{\circ} \mathrm{C}$ ). Using Emitcalc the spectral absorptance was then calculated from $1-\rho_{t, \lambda}$ and the data was convoluted into the blackbody curve for the temperature of interest and integrated to give the thermal emittance.

\section{Durability Testing}

Atomic Oxygen. Samples were exposed to atomic oxygen in an RF plasma asher operated on air at ambient temperature. The samples were exposed to a total effective fluence of $1.61 \times 10^{21}$ atoms $/ \mathrm{cm}^{2}$, based on the mass loss of a polyimide Kapton witness coupon. The effective fluence was calculated from Kapton's known erosion yield in space of $3.0 \times 10^{-24} \mathrm{~cm}^{3} /$ atom.

Vacuum Heat Treatment. Samples which were exposed to atomic oxygen were then exposed to two separate vacuum heat treatments at $2000{ }^{\circ} \mathrm{C}$ with a vacuum of between $2.0 \times 10^{-5}$ to $6.5 \times 10^{-6}$ torr. A temperature of $2000^{\circ} \mathrm{C}$ was chosen to simulate the hot spot temperature prior to knowing what the actual temperature would be. Tantalum foil was used to wrap the samples to act as an oxygen getter during high temperature exposure. Temperature ramping was monitored to achieve maxium vacuum during heat-up. Ramp up time was $10 \mathrm{hr}$, soak at $2000^{\circ} \mathrm{C}$ was $1 \mathrm{hr}$, and ramp down was $1 / 2 \mathrm{hr}$. After optical characterization, the heat treated samples were examined in a scanning electron microscope (SEM) and compared to similarly grit-blast samples which had not been durability tested.

\section{Results and Discussion}

A total of 60 sets of data were obtained for optical property characterization. In general grit-blasting was found to be effective in decreasing the specular reflectance and the $\alpha_{s} / \varepsilon$ ratios of the refractory foils. The placement of a screen was found to further enhance these optical properties, with a grit-blast screen covering a grit-blast foil being most effective.

Molybdenum Foil. The results of grit-blasting Mo foil are listed in Table I. The $\alpha_{\mathrm{s}}$ of the grit blasted Mo aperture shield samples ranged from 0.396 to 0.696 . Differences in optical properties are due to a difference in pressure, distance, and grit-blast material. The best results for these samples were achieved with an $\mathrm{Al}_{2} \mathrm{O}_{3}$ grit applied at $45 \mathrm{psi}$ at a distance of $<1$ in. This treatment dropped $\rho_{t}$ to 0.304 and $\rho_{\mathrm{s}}$ to 0.001 . This is significantly better than values for pristine Mo which show $\rho_{t}$ to be approximately 0.6 and $\rho_{\mathrm{s}}$ to be on the order of 0.4 . Absorptance over emittance ratios for 2600 and $1900^{\circ} \mathrm{C}$ dropped from 1.7 to 1.2 and from 2.3 to 1.3 respectively. Even though these results are very good, Mo was subsequently excluded as an aperture shield candidate material because its melting temperature was decided to be too close to the estimated temperature that would be achieved during off pointing, and that would warrant an unnecessary safety risk.

Black Rhenium Coated W Foil. Black Re coated 0.001 in. thick $W$ provided excellent optical properties. The $\alpha_{\mathrm{s}}$ was 0.981 , the $\rho_{\mathrm{s}}$ was 0.000 , and the $\alpha_{\mathrm{s}} / \varepsilon$ ratios for 2600 and $1900^{\circ} \mathrm{C}$ were both 1.1. The addition of a black 
Re coated W screen ( 0.01 in. diameter, $10 \times 10$ mesh) dropped $\alpha_{s} / \varepsilon_{2600}{ }^{\circ} \mathrm{C}$ to 1.0. Unfortunately, the black Re was found to be very unstable in the atomic oxygen environment and contaminated the other samples. Therefore, the black Re coated foil and screen were eliminated as potential aperture shield candidate materials and no further tests were conducted.

Tungsten Foils and Screens. The effect of grit-blasting on the optical properties of $W$ foil are presented in Table II. The various $\mathrm{W}$ foil thickness and grit-blasting conditions are listed in Table II. The $\alpha_{s}$ of the grit-blasted W samples ranged from 0.469 to 0.669 . Like the Mo foil samples, the differences in optical properties are due to a difference in grit, pressure, and distance. The best results for these samples were achieved with $\mathrm{Al}_{2} \mathrm{O}_{3}$ grit applied at $35 \mathrm{psi}$ at a distance of $1 \mathrm{in}$. This treatment dropped $\rho_{\mathrm{t}}$ to 0.346 to 0.398 and $\rho_{\mathrm{s}}$ to 0.006 to 0.037 (samples WA6GB and WA7GB, respectively). This is significantly better than values for pristine $W$ which had $\rho_{t}$ of 0.552 to 0.569 and $\rho_{\mathrm{s}}$ of 0.365 to 0.480 for the two sides of the as received foil. Absorptance over emittance ratios for $2600{ }^{\circ} \mathrm{C}$ and $1900^{\circ} \mathrm{C}$ dropped from 1.5 to 1.6 to 1.3 to 1.4 and from 2.2 to 1.6 to 1.8 , respectively. Originally 0.001 in. thick W foils were treated. Samples of 0.002 " thick were treated with the most promising grit-blast conditions (samples W1BGB and W2BGB). Slight improvements in the optical properties were observed for the thicker foil samples.

Table III lists the W screens which were placed over the $\mathrm{W}$ foil samples. Table IV lists the various screens (pristine and grit-blast) which were placed over the foils (pristine and grit-blast) and their corresponding optical properties. The addition of a screen generally decreased both the specular reflectance and the $\alpha_{\mathrm{s}} / \mathrm{E}$ ratios slightly. The addition of a grit-blast screen further decreased the values. For example, grit-blast foil WA6GB had $\alpha_{s} / \varepsilon$ ratios at 2600 and $1900^{\circ} \mathrm{C}$ of 1.3 and 1.6 , respectively and $\rho_{\mathrm{s}}$ of 0.006 . The addition of a pristine screen (WS1) drops the $\alpha_{\mathrm{s}} / \varepsilon$ ratio at $1900{ }^{\circ} \mathrm{C}$ to 1.5 (it stayed the same at $2600{ }^{\circ} \mathrm{C}$ ), and $\rho_{\mathrm{s}}$ stayed at 0.006 . The addition of a gritblast screen (WSA10G) dropped the $\alpha_{s} / \varepsilon$ ratios at $2600^{\circ} \mathrm{C}$ and $1900^{\circ} \mathrm{C}$ to 1.2 and 1.4 , respectively, and $\rho_{s}$ decreased to 0.005 .

Based on the optical property enhancement results, one W foil sample (WA6GB) and two W screens (WS1, WSA 10G) were AO durability tested along with black Re samples. The black Re was found to degrade under the AO environment and contaminated the $W$ samples. New $W$ foil samples (WA7GB and WA9GB) and screens (WS2 and WSA1 IG) were then exposed to AO and VHT for durability testing. The optical properties for $\mathrm{AO}$ and VHT exposures for these samples are listed in Table V.
Atomic oxygen caused a slight decrease in $\rho_{\mathrm{s}}$ and increase in $\alpha_{s}$, and essentially no change in $\varepsilon$. The $\alpha_{s} / \varepsilon$ ratios generally remained the same. The changes in $\rho$ and $\alpha$ may be due to the formation of tungsten oxide (de Groh 92). Exposure to the initial VHT caused a slight increase in $\rho_{s}$ and significant decreases in $\alpha_{s}$ and $\varepsilon$. These changes are most noticeable with the foil samples not covered with a screen. Although there were significant changes in $\alpha_{\mathrm{s}}$ and $\varepsilon$, the $\alpha_{s} / \varepsilon$ ratios remained essentially the same. Only slight increases in $\alpha_{s} / \varepsilon$ occurred, typically with the first VHT exposure. The $\rho_{s}$ and $\alpha_{s}$ remained essentially unchanged with the second VHT exposure, implying that the optical properties should become stable with time. The effect of grit-blasting on improving optical properties and high temperature exposure on decreasing optical properties of grit-blasted metals is well know (Bice 85, Touloukian 70, de Groh 92).

The foil samples were found to be brittle after VHT with corner pieces breaking off when handled, as seen in the photograph in Fig. 4. Grain growth was evident and can be seen as bright and dark areas in Fig. 4. Grain growth and embrittlement is consistent with the fact that VHT was conducted in excess of tungsten's recrystallization temperature $\left(\approx 1,300^{\circ} \mathrm{C}\right)$. Surface examination with SEM revealed a smoothing of the grit-blast texture, as one might expect due to high temperature relaxation. Figures 5 and 6 compare the surface morphologies of a grit-blast sample which was not heat treated (WA12GB) with a sample that was atomic oxygen exposed and heat treated, WA7GB. The smoothing does not appear to become more pronounced with the second VHT (compare Figs. 5(b) and (c)). Also evident during SEM examination was grain structures in the heated sample, as seen by both boundaries (see the fine lines in Figs. 6(b) and (c)) and dark and light regions. Cracking at the grain boundaries was also visible as seen in Figs. 5(b) and (c). Cracking appeared more numerous and severe after the second VHT (again compare Figs. 5(b) and (c)).

As a result of this test program, grit-blasted $\left(\mathrm{Al}_{2} \mathrm{O}_{3}\right.$ grit, 120 grit size, applied at 35 psi at a distance of $1 \mathrm{in}$.) 2 mil tungsten foil was chosen for the exterior layer of the SDFD heat receiver aperture shield. A 0.007 in. diameter wire, $20 \times 20$ mesh tungsten screen was chosen to cover the tungsten foil. The resulting optical properties for this foil and screen combination (W1BGB and WSPRIS) were $\rho_{\mathrm{s}}=0.006, \varepsilon_{2600{ }^{\circ} \mathrm{C}}=1.2$ and $\varepsilon_{1900{ }^{\circ} \mathrm{C}}=1.4$. Although a grit-blast screen provided the best optical properties, it was not chosen for programmatic reasons. The center support ring (shown in Fig. 3) has also been grit-blasted for optical property enhancement. The company contracted by AlliedSignal to build the aperture shield, A.D.D., produced a test sample of the chosen foil material and grit- 
blasting conditions. Optical properties were obtained for this A.D.D. sample (W3GB) to verify the optical properties of the aperture shield production line. As seen in Table II, the values vary somewhat from the AlliedSignal grit-blast 2 mil thick foils (W1BGB and W2BGB).

A heat receiver aperture shield test unit has been built with the screen covered grit-blast tungsten foil exterior layers (see Fig. 7). The aperture shield has been thermal shock tested twice in LeRC's SDGTD system utilizing the solar simulator and solar concentrator to evaluate the effectiveness of the optical property enhanced surfaces in maintaining acceptable temperatures during a period of off-pointing (Kerslake 97). To demonstrate the structural adequacy of the aperture shield outer MFI layers under severe solar thermal loading, test conditions were set up to achieve a peak solar flux of $80 \mathrm{~W} / \mathrm{cm}^{2}$ on the aperture shield test article, the expected solar beam during offpointed on MIR (Kerslake 97, Strumpf 97). Nearequilibrium temperatures of $1862 \mathrm{~K}\left(1,589^{\circ} \mathrm{C}\right)$ and $2072 \mathrm{~K}$ $\left(1,799^{\circ} \mathrm{C}\right)$ were attained in the centers of the hot spots during the two 1 hour exposures (Kerslake 97). High-flux testing was found to be successful and is described in detail by Kerslake. It should be noted that although the VHT samples became embrittled, there was no visible signs of foil cracking in the flux impingement zone with thermal shock testing (Kerslake 97). A full-size aperture shield assembly for the heat receiver component of the joint U.S./Russian SDFD program has been fabricated (Strumpf 97).

\section{Conclusions}

Molybdenum and tungsten foils and tungsten screens were grit-blast for optical property enhancement for SD heat receiver aperture shield applications. Based on the optical property enhancement results, samples were atomic oxygen and high temperature vacuum heat treatment durability tested. Alumina grit-blasted (120 grit at 35 psi pressure and $1 \mathrm{in}$. distance) 2 mil tungsten foil was chosen for the exterior layer of the SDFD heat receiver aperture shield. A 0.007 in. diameter wire, $20 \times 20$ mesh tungsten screen was chosen to cover the tungsten foil. The aperture center support ring was also grit-blasted for optical property enhancement. Based on this test program, a heat receiver aperture shield test unit has been built by Aerospace
Design and Development with the screen covered gritblast tungsten foil exterior layers. The aperture shield test unit was thermal shock tested in LeRC's SDGTD system to evaluate the effectiveness of the optical property enhanced exterior layer in maintaining temperature and structure during a period of off-pointing. Thermal shock testing of the aperture shield test article was successful. A full-size aperture shield assembly was fabricated for the heat receiver component of the joint U.S./Russian SDFD program.

\section{References}

V.C. Bice and D.L. Jacobson, "Emissivity Data for Metals at High Temperature," AIAA 85-0987, 1985.

K K. de Groh, S.K. Rutledge, C.A.Burke, T M. Dever, R.M. Olle and J.A. Terlep, "Low Earth Orbit Durability Evaluation of Haynes 188 Solar Receiver Material," AIAA 92-0850, 1992.

K.K. de Groh, D.M. Roig, C.A. Burke and D.R. Shah, "Performance and Durability of High Emittance Heat Receiver Surfaces for Solar Dynamic Power Systems," NASA TM-106549, 1994.

T.W. Kerslake, L.S. Mason and H.J. Strumpf, "HighFlux, High-Temperature Thermal Vacuum Qualification Testing of a Solar Receiver Aperture Shield,"NASA TM-107505, IECEC-97237, 1997.

R.K. Shaltens and R.V. Boyle, "Initial Results from the Solar Dynamic (SD) Ground Test Demonstration (GTD) Project at NASA Lewis," NASA TM-107004, IECEC-95421, 1995.

R.K. Shaltens and L.S. Mason, "Early Results from Solar Dynamic Space Power System Testing," NASA TM-107252, 1996.

H.J. Strumpf, et. al. "Fabrication and Testing of the Solar Dynamic Ground Test Demonstrator Heat Receiver," Proc. 29th IECEC, 1994, pp. 372-377.

H.J. Strumpf, T. Trinh, W. Westenlaken, C. Krystkowiak, V. Avanessian and T.W. Kerslake, "Design and Analysis of the Aperture Shield Assembly for a Space Solar Receiver," NASA TM-107500, IECEC97347, 1997.

Y.S. Touloukian, et. al. Thermophysical Properties of Matter, Vol. 7: "Thermal Radiative PropertiesMetallic Elements and Alloys," IFI/Plenum, New York-Washington, 1970, pp. 796-804. 
TABLE L. OPTICAL PROPERTIES OF MO FOIL APERTURE SHIELD SAMPLES

\begin{tabular}{|c|c|c|c|c|c|c|c|}
\hline Sample description & Sample name & $\rho$ & $\alpha_{s}$ & $\varepsilon_{2500^{\circ} \mathrm{C}}$ & $\varepsilon_{1900^{\circ} \mathrm{C}}$ & $\alpha_{1} / \varepsilon_{2600} \circ \mathrm{c}$ & $\alpha_{\mathrm{g}} / \varepsilon_{1900^{\circ} \mathrm{C}}$ \\
\hline $\begin{array}{l}0.001 \text { in. Mo } \\
\text { Pristine, convex }\end{array}$ & MOFVP & $\begin{array}{l}\text { T } 0.632 \\
\text { D: } 0.217 \\
\text { S: } 0.415 \\
\end{array}$ & 0.368 & 0.22 & 0.16 & 1.7 & 2.3 \\
\hline $\begin{array}{c}0.001 \text { in. Mo } \\
\text { Pristine, concave }\end{array}$ & MOFCP & $\begin{array}{l}\text { T: } 0.599 \\
\text { D: } 0.167 \\
\text { S: } 0.432\end{array}$ & 0.401 & 0.25 & 0.18 & 1.6 & 2.2 \\
\hline $\begin{array}{c}0.001 \text { in. Mo } \\
\text { SiC, } 70 \text { psi, } 10 \text { in. }\end{array}$ & MOA8GB & $\begin{array}{l}\text { T: } 0.604 \\
\text { D: } 0.575 \\
\text { S: } 0.029 \\
\end{array}$ & 0.396 & 0.22 & 0.15 & 1.8 & 2.4 \\
\hline $\begin{array}{c}0.001 \text { in. Mo } \\
\text { SiC, } 70 \mathrm{psi}, 06 \text { in. }\end{array}$ & MOA9GB & $\begin{array}{l}\text { T: } 0.548 \\
\text { D: } 0.544 \\
\text { S: } 0.004\end{array}$ & 0.452 & 0.27 & 0.19 & 1.7 & 2.4 \\
\hline $\begin{array}{c}0.001 \text { in. Mo } \\
\text { SiC, } 70 \mathrm{psi}, 03 \text { in. }\end{array}$ & MOA10G & $\begin{array}{l}\text { T: } 0.417 \\
\text { D: } 0.416 \\
\text { S: } 0.001\end{array}$ & 0.583 & 0.40 & 0.31 & 1.5 & 1.9 \\
\hline $\begin{array}{c}0.001 \text { in. Mo } \\
\mathrm{Al}_{2} \mathrm{O}_{3}, 45 \mathrm{psi}, 08 \mathrm{in} .\end{array}$ & MOA11G & $\begin{array}{l}\text { T: } 0.427 \\
\text { D: } 0.413 \\
\text { S: } 0.014\end{array}$ & 0.573 & 0.41 & 0.33 & 1.4 & 1.7 \\
\hline $\begin{array}{c}0.001 \text { in. Mo } \\
\mathrm{Al}_{2} \mathrm{O}_{3}, 45 \text { psi, } 03 \text { in. }\end{array}$ & MOA12G & $\begin{array}{l}\text { T: } 0.344 \\
\text { D: } 0.343 \\
\text { S: } 0.001\end{array}$ & 0.656 & 0.54 & 0.48 & 1.2 & 1.4 \\
\hline $\begin{array}{c}0.001 \text { in. Mo } \\
\mathrm{Al}_{2} \mathrm{O}_{3}, 45 \mathrm{psi}, 01 \mathrm{in} .\end{array}$ & MOA13G & $\begin{array}{l}\text { T: } 0.354 \\
\text { D: } 0.348 \\
\text { S: } 0.007\end{array}$ & 0.646 & 0.53 & 0.48 & 12 & 1.3 \\
\hline $\begin{array}{c}0.001 \text { in. Mo } \\
\mathrm{Al}_{2} \mathrm{O}_{3}, 45 \text { psi, }<1 \text { in. }\end{array}$ & MOA14G & $\begin{array}{l}\text { T: } 0.304 \\
\text { D:0.303 } \\
\text { S: } 0.001\end{array}$ & 0.696 & 0.59 & 0.54 & 12 & 1.3 \\
\hline
\end{tabular}


TABLE II-OPTICAL PROPE RTIES OF TUNGSTEN FOIL SAMPLES

\begin{tabular}{|c|c|c|c|c|c|c|c|}
\hline Sample description & Sample name & $p$ & $\alpha_{s}$ & $\varepsilon_{2600}{ }^{\circ} \mathrm{C}$ & $\varepsilon_{1900^{\circ} \mathrm{C}}$ & $\alpha_{\mathrm{s}} / \varepsilon_{26000^{\circ} \mathrm{C}}$ & $\alpha, / \varepsilon_{1900^{\circ} \mathrm{C}}$ \\
\hline $\begin{array}{c}0.001 \text { in. } W \\
\text { Pristine convex }\end{array}$ & WFPX & $\begin{array}{l}\text { T: } 0.569 \\
D: 0.203 \\
\text { S: } 0.365\end{array}$ & 0.431 & 0.28 & 0.20 & 1.5 & 2.2 \\
\hline $\begin{array}{c}0.001 \text { in. } W \\
\text { Pistine concave }\end{array}$ & WFPV & $\begin{array}{l}\text { T: } 0.552 \\
\text { D: } 0.072 \\
\text { S: } 0.480 \\
\end{array}$ & 0.448 & 0.28 & 0.20 & 1.6 & 2.2 \\
\hline $\begin{array}{c}0.001 \text { in. } W \\
\text { SiC, } 70 \text { psi, } 9 \text { in. }\end{array}$ & WA4GB & $\begin{array}{l}\text { T: } 0.531 \\
\mathrm{D}: 0.275 \\
\text { S: } 0.256 \\
\end{array}$ & 0.469 & 0.29 & 0.21 & 1.6 & 2.2 \\
\hline $\begin{array}{c}0.001 \text { in. } W \\
\mathrm{Al}_{2} \mathrm{O}_{3} \text { (120 grit) } \\
35 \text { psi, } 1 \text { in. }\end{array}$ & WA6GB & $\begin{array}{l}\text { T: } 0.346 \\
\text { D: } 0.340 \\
\text { S: } 0.006\end{array}$ & 0.654 & 0.51 & 0.42 & 1.3 & 1.6 \\
\hline $\begin{array}{c}0.001 \text { in. } \mathrm{W} \\
\mathrm{Al}_{2} \mathrm{O}_{3} \text { (120 grit) } \\
35 \text { psi, } 1 \text { in. }\end{array}$ & WA7GB & $\begin{array}{l}\text { T: } 0.398 \\
\text { D: } 0.361 \\
\text { S: } 0.037 \\
\end{array}$ & 0.602 & 0.44 & 0.34 & 1.4 & 1.8 \\
\hline $\begin{array}{c}0.001 \text { in. W } \\
\mathrm{Al}_{2} \mathrm{O}_{3} \text { (120 grit) } \\
35 \text { psi, } 2 \text { in. }\end{array}$ & WA8GB & $\begin{array}{l}\text { T: } 0.375 \\
D: 0.358 \\
\text { S: } 0.017 \\
\end{array}$ & 0.625 & 0.47 & 0.37 & 1.3 & 1.7 \\
\hline $\begin{array}{c}0.001 \text { in. } \mathrm{W} \\
\mathrm{Al}_{2} \mathrm{O}_{3} \text { (120 grit) } \\
45 \text { psi, } 2 \text { in. } \\
\end{array}$ & WA9GB & $\begin{array}{l}\text { T: } 0.446 \\
\text { D: } 0.376 \\
\text { S: } 0.070 \\
\end{array}$ & 0.554 & 0.38 & 0.29 & 15 & 1.9 \\
\hline $\begin{array}{c}0.001 \text { in. } \mathrm{W} \\
\mathrm{Al}_{2} \mathrm{O}_{3} \text { (120 grit) } \\
45 \text { psi, } 3 \text { in. }\end{array}$ & WA12GB & $\begin{array}{l}T: 0.448 \\
D: 0.365 \\
S: 0.083 \\
\end{array}$ & 0.552 & 0.39 & 0.29 & 1.4 & 1.9 \\
\hline $\begin{array}{c}0.002 \text { in. } \mathrm{W} \text { foil, \# } 1 \\
\mathrm{Al}_{2} \mathrm{O}_{3}(120 \text { grit }) \\
35 \mathrm{psi}, 1 \text { in. }\end{array}$ & W1BGB & $\begin{array}{l}\text { T: } 0.331 \\
\text { D: } 0.325 \\
\text { S: } 0.006 \\
\end{array}$ & 0.669 & 0.55 & 0.49 & 1.2 & 1.4 \\
\hline $\begin{array}{c}0.002 \text { in. } W \text { foil, \#2 } \\
\mathrm{Al}_{2} \mathrm{O}_{3} \text { (120 grit) } \\
35 \text { psi, } 1 \text { in. } \\
\end{array}$ & W2BGB & $\begin{array}{l}\text { T: } 0.372 \\
\text { D: } 0.350 \\
\text { S: } 0.022 \\
\end{array}$ & 0.628 & 0.49 & 0.41 & 1.3 & 1.5 \\
\hline $\begin{array}{l}\text { A.D.D. } 0.002 \text { in. } W \text { foil } \\
\mathrm{Al}_{2} \mathrm{O}_{3}(120 \text { grit }) \\
35 \text { psi }\end{array}$ & W3GB & $\begin{array}{l}\text { T: } 0.409 \\
\text { D: } 0.370 \\
\text { S: } 0.039\end{array}$ & 0.591 & 0.45 & 0.36 & 1.3 & 1.6 \\
\hline
\end{tabular}

TABLE III.-TUNGSTEN SCREENS

\begin{tabular}{|c|c|}
\hline Sample description & $\begin{array}{c}\text { Sample } \\
\text { name }\end{array}$ \\
\hline $\begin{array}{l}10 \times 10 \text { mesh, } 0.01 \text { in. dia. W screen } \\
\text { Pristine }\end{array}$ & $\begin{array}{l}\text { WS1 } \\
\text { WS2 }\end{array}$ \\
\hline $\begin{array}{l}10 \times 10 \text { mesh, } 0.01 \text { in. dia. W screen } \\
\mathrm{Al}_{2} \mathrm{O}_{3}(120 \text { grit }), 45 \mathrm{psi},<1 \text { in. }\end{array}$ & $\begin{array}{l}\text { WSA10G } \\
\text { WSA11G }\end{array}$ \\
\hline $\begin{array}{l}10 \times 10 \text { mesh, } 0.01 \text { in. dia. W screen } \\
\mathrm{SiC}, 70 \mathrm{psi},<1 \text { in. }\end{array}$ & WSA5GB \\
\hline $\begin{array}{l}20 \times 20 \text { mesh, } 0.007 \text { in. dia. W screen } \\
\text { Pristine }\end{array}$ & WSPRIS \\
\hline $\begin{array}{c}20 \times 20 \text { mesh, } 0.007 \text { in. dia. W screen } \\
\mathrm{Al}_{2} \mathrm{O}_{3}(120 \text { grit }), 45 \mathrm{psi}, 1 \mathrm{in} .\end{array}$ & WSFGB \\
\hline $\begin{array}{c}20 \times 20 \text { mesh, } 0.007 \text { in. dia. W screen } \\
\mathrm{Al}_{2} \mathrm{O}_{3}(120 \text { grit }), 50 \text { psi, } 1 \text { in. }\end{array}$ & WSGGB \\
\hline $\begin{array}{c}30 \times 30 \text { mesh, } 0.004 \text { in. dia. W screen } \\
\text { Pristine }\end{array}$ & WS3 \\
\hline $\begin{array}{c}35 \times 35 \text { mesh, } 0.003 \text { in. dia. W screen } \\
\text { Pristine }\end{array}$ & WS4 \\
\hline $\begin{array}{c}40 \times 40 \text { mesh, } 0.003 \text { in. dia. W screen } \\
\text { Pristine }\end{array}$ & WS5 \\
\hline $\begin{array}{c}50 \times 50 \text { mesh, } 0.002 \text { in. dia. W screen } \\
\text { Pristine }\end{array}$ & WS6 \\
\hline
\end{tabular}


TABLE IV. - OPTICAL PROPERTIES OF W SCREEN COVERED W FOIL SAMPLES

\begin{tabular}{|c|c|c|c|c|c|c|c|}
\hline Sample description & Sample name & $\rho$ & $\alpha_{s}$ & $E_{2600^{\circ} \mathrm{C}}$ & $E_{1900^{\circ} \mathrm{C}}$ & $\alpha_{s} / \varepsilon_{2600}{ }^{\circ} \mathrm{c}$ & $\alpha_{3} / \varepsilon_{1900^{\circ} \mathrm{C}}$ \\
\hline $\begin{array}{c}\text { WFPV } \\
\text { and } \\
\text { WS1 }\end{array}$ & WFWSP & $\begin{array}{l}\mathrm{T}: 0.452 \\
\mathrm{D}: 0.122 \\
\mathrm{~S}: 0.330\end{array}$ & 0.548 & 0.36 & 0.26 & 15 & 2.1 \\
\hline $\begin{array}{c}\text { WA4GB } \\
\text { and } \\
\text { WSA5GB }\end{array}$ & W4P5 & $\begin{array}{l}\text { T: } 0.467 \\
\text { D: } 0.246 \\
\text { S: } 0.221\end{array}$ & 0.533 & 0.35 & 0.26 & 1.5 & 2.1 \\
\hline $\begin{array}{c}\text { WA6GB } \\
\text { and } \\
\text { WS1 }\end{array}$ & W6PWS1 & $\begin{array}{l}\mathrm{T}: 0.286 \\
\mathrm{D}: 0.280 \\
\mathrm{~S}: 0.006\end{array}$ & 0.714 & 0.56 & 0.47 & 1.3 & 15 \\
\hline $\begin{array}{c}\text { WA6GB } \\
\text { and } \\
\text { WSA10G }\end{array}$ & W6P10 & $\begin{array}{l}\text { T: } 0.273 \\
\text { D: } 0.268 \\
\text { S: } 0.005\end{array}$ & 0.727 & 0.60 & 0.52 & 1.2 & 1.4 \\
\hline $\begin{array}{c}\text { WA6GB } \\
\text { and } \\
\text { WSA11G }\end{array}$ & W6P11 & $\begin{array}{l}\text { T: } 0.291 \\
\text { D: } 0.284 \\
\text { S: } 0.007\end{array}$ & 0.709 & 0.58 & 0.49 & 1.2 & 1.4 \\
\hline $\begin{array}{c}\text { WA7GB } \\
\text { and } \\
\text { WS1 }\end{array}$ & W7PWS1 & $\begin{array}{l}\text { T: } 0.335 \\
D: 0.290 \\
\text { S: } 0.045\end{array}$ & 0.665 & 0.48 & 0.38 & 1.4 & 1.8 \\
\hline $\begin{array}{c}\text { WA7GB } \\
\text { and } \\
\text { WSA10G }\end{array}$ & W7P10 & $\begin{array}{l}\text { T: } 0.337 \\
\text { D: } 0.286 \\
\text { S: } 0.051\end{array}$ & 0.663 & 0.51 & 0.42 & 13 & 1.6 \\
\hline $\begin{array}{c}\text { WA8GB } \\
\text { and } \\
\text { WS1 }\end{array}$ & W8PWS1 & $\begin{array}{l}\text { T: } 0.309 \\
D: 0.293 \\
S: 0.016\end{array}$ & 0.691 & 0.52 & 0.42 & 1.3 & 1.6 \\
\hline $\begin{array}{c}\text { WA8GB } \\
\text { and } \\
\text { WSA10G }\end{array}$ & W8P10 & $\begin{array}{l}\text { T: } 0.327 \\
D: 0.301 \\
\text { S: } 0.027\end{array}$ & 0.673 & 0.53 & 0.44 & 1.3 & 1.5 \\
\hline $\begin{array}{c}\text { WA9GB } \\
\text { and } \\
\text { WSA10G }\end{array}$ & W9P10 & $\begin{array}{l}\text { T: } 0.370 \\
\text { D: } 0.293 \\
\text { S: } 0.077\end{array}$ & 0.630 & 0.48 & 0.39 & 1.3 & 1.6 \\
\hline $\begin{array}{c}\text { WA12GB } \\
\text { and } \\
\text { WSA } 10 G\end{array}$ & W12P10 & $\begin{array}{l}\mathrm{T}: 0.368 \\
\mathrm{D}: 0.293 \\
\mathrm{~S}: 0.075\end{array}$ & 0.632 & 0.47 & 0.38 & 13 & 1.7 \\
\hline $\begin{array}{c}\text { WAI2GB } \\
\text { and } \\
\text { WSA11G }\end{array}$ & W12P11 & $\begin{array}{l}\text { T: } 0.351 \\
\text { D: } 0.229 \\
\text { S: } 0.052\end{array}$ & 0.649 & 0.49 & 0.40 & 1.3 & 1.6 \\
\hline $\begin{array}{c}\text { WA12GB } \\
\text { and } \\
\text { WS3 }\end{array}$ & W12P3 & $\begin{array}{l}\text { T: } 0.351 \\
D: 0.274 \\
\text { S: } 0.076\end{array}$ & 0.649 & 0.47 & 0.39 & 1.4 & 1.7 \\
\hline $\begin{array}{c}\text { WA12GB } \\
\text { and } \\
\text { WS4 }\end{array}$ & W12P4 & $\begin{array}{l}\text { T: } 0.348 \\
\text { D: } 0.281 \\
\text { S: } 0.067\end{array}$ & 0.652 & 0.47 & 0.38 & 1.4 & 1.7 \\
\hline $\begin{array}{c}\text { WA12GB } \\
\text { and } \\
\text { WS5 }\end{array}$ & W12P5 & $\begin{array}{l}\text { T: } 0.348 \\
\text { D: } 0.270 \\
\text { S: } 0.077\end{array}$ & 0.652 & 0.49 & 0.41 & 1.3 & 1.6 \\
\hline $\begin{array}{c}\text { WA12GB } \\
\text { and } \\
\text { WS6 }\end{array}$ & W12P6 & $\begin{array}{l}\text { T: } 0.340 \\
\text { D: } 0.274 \\
\text { S: } 0.066\end{array}$ & 0.660 & 0.50 & 0.42 & 1.3 & 1.6 \\
\hline 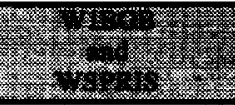 & 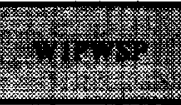 & (3) & 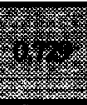 & (x) & 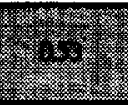 & 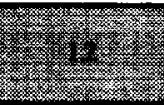 & 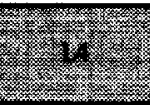 \\
\hline $\begin{array}{l}\text { W1BGB } \\
\text { and } \\
\text { WSFGB }\end{array}$ & W1PWSF & $\begin{array}{l}T: 0.258 \\
D: 0.253 \\
S: 0.005\end{array}$ & 0.742 & 0.64 & 0.58 & 1.2 & 13 \\
\hline $\begin{array}{c}\text { W1BGB } \\
\text { and } \\
\text { WSGGB }\end{array}$ & W1PWSG & $\begin{array}{l}\text { T: } 0.253 \\
D: 0.248 \\
\text { S: } 0.005\end{array}$ & 0.747 & 0.65 & 0.59 & 1.1 & 13 \\
\hline $\begin{array}{c}\text { W2BGB } \\
\text { and } \\
\text { WSFGB }\end{array}$ & W2PWSF & $\begin{array}{l}\text { T: } 0.268 \\
\text { D: } 0.260 \\
\text { S: } 0.009\end{array}$ & 0.732 & 0.61 & 0.56 & 12 & 1.3 \\
\hline $\begin{array}{c}\text { W2BGB } \\
\text { and } \\
\text { WSGGB }\end{array}$ & W2PWSG & $\begin{array}{l}\text { T: } 0.272 \\
\text { D: } 0.260 \\
\text { S: } 0.012\end{array}$ & 0.728 & 0.61 & 0.55 & 1.2 & 13 \\
\hline $\begin{array}{c}\text { W3GB } \\
\text { and } \\
\text { WSGGB }\end{array}$ & W3PWSG & $\begin{array}{l}\mathrm{T}: 0.317 \\
\mathrm{D}: 0.291 \\
\mathrm{~S}: 0.027\end{array}$ & 0.683 & 0.55 & 0.48 & 1.2 & 1.4 \\
\hline
\end{tabular}


TABLE V.-OPTICAL PROPERTIES OF DURABILITY TESTED SAMPLES

\begin{tabular}{|c|c|c|c|c|c|}
\hline Sample description & Sample id. & Pristine & $\mathrm{AO}$ & VHT 1 & VHT 2 \\
\hline $\begin{array}{c}0.001 \text { in. } W \text { foil } \\
\mathrm{Al}_{2} \mathrm{O}_{3} \text { (120 grit), } 35 \text { psi, } 1 \text { in. }\end{array}$ & WA7GB & $\begin{array}{c}\alpha_{\mathrm{s}}: 0.602 \\
\rho_{\mathrm{t}}: 0.398 \\
\rho_{\mathrm{s}}: 0.037 \\
\alpha_{\mathrm{s}} / \varepsilon_{2600 \%}: 1.4 \\
\alpha_{\mathrm{s}} / \varepsilon_{19000 \mathrm{C}}: 1.8\end{array}$ & $\begin{array}{c}\alpha_{s}: 0.627 \\
\rho_{t}: 0.373 \\
\rho_{s}: 0.030 \\
\alpha_{s} / \varepsilon_{26000^{\circ} \mathrm{C}}: 1.4 \\
\alpha_{s} / \varepsilon_{1900^{\circ} \mathrm{C}}: 1.8\end{array}$ & $\begin{array}{c}\alpha_{\mathrm{s}}: 0.445 \\
\rho_{\mathrm{t}}: 0.555 \\
\rho_{\mathrm{s}}: 0.097 \\
\alpha_{\mathrm{s}} / \varepsilon_{26000^{\circ} \mathrm{C}}: 1.5 \\
\alpha_{\mathrm{s}} / \varepsilon_{19000^{\circ} \mathrm{C}}: 2.0\end{array}$ & $\begin{array}{c}\alpha_{s}: 0.445 \\
\rho_{t}: 0.555 \\
\rho_{s}: 0.074 \\
\alpha_{s} / \varepsilon_{26000 \mathrm{C}}: 1.5 \\
\alpha_{\mathrm{s}} \varepsilon_{1900^{\circ} \mathrm{C}}: 2.0\end{array}$ \\
\hline $\begin{array}{c}\text { WA7GB } \\
\text { and } \\
\text { Pristine } W \text { screen } \\
0.01 \text { in. dia.. } 10 \times 10 \text { mesh }\end{array}$ & $\begin{array}{l}\text { WA7GB } \\
\text { and } \\
\text { WS2* }\end{array}$ & $\begin{array}{c}\alpha_{\mathrm{s}}: 0.665 \\
\rho_{\mathrm{t}}: 0.335 \\
\rho_{\mathrm{s}}: 0.045 \\
\alpha_{\mathrm{s}} / \varepsilon_{2600^{\circ} \mathrm{C}}: 1.4 \\
\alpha_{s} / \varepsilon_{1900^{\circ} \mathrm{C}}: 1.8\end{array}$ & $\begin{array}{c}\alpha_{\mathrm{s}}: 0.666 \\
\rho_{\mathrm{l}}: 0.334 \\
\rho_{\mathrm{s}}: 0.050 \\
\alpha_{\mathrm{s}} / \varepsilon_{2600^{\circ} \mathrm{c}}: 1.4 \\
\alpha_{\mathrm{s}} / \varepsilon_{1900^{\circ} \mathrm{c}}: 1.9\end{array}$ & $\begin{array}{c}\alpha_{\mathrm{s}}: 0.519 \\
\rho_{1}: 0.481 \\
\rho_{\mathrm{s}}: 0.046 \\
\alpha_{\mathrm{s}} / \varepsilon_{2600^{\circ} \mathrm{C}}: 1.4 \\
\alpha_{s} / \varepsilon_{1900^{\circ} \mathrm{C}}: 1.9\end{array}$ & $\begin{array}{c}\alpha_{\mathrm{s}}: 0.512 \\
\rho_{1}: 0.488 \\
\rho_{\mathrm{s}}: 0.046 \\
\alpha_{s} / \varepsilon_{2600^{\circ} \mathrm{c}}: 1.4 \\
\alpha_{s} / \varepsilon_{1900 \mathrm{c}}: 1.9\end{array}$ \\
\hline $\begin{array}{c}\text { WA7GB } \\
\text { and } \\
10 \times 10 \text { mesh, } 0.01 \text { in. dia. } W \text { screen } \\
\mathrm{Al}_{2} \mathrm{O}_{3}(120 \text { grit }), 45 \mathrm{psi},<1 \text { in. }\end{array}$ & $\begin{array}{l}\text { WA7GB } \\
\text { and } \\
\text { WSA11G* }\end{array}$ & $\begin{array}{c}\alpha_{\mathrm{s}}: 0.663 \\
\rho_{1}: 0.337 \\
\rho_{\mathrm{s}}: 0.051 \\
\alpha_{\mathrm{s}} / \varepsilon_{2000 \mathrm{C}}: 1.3 \\
\alpha_{\mathrm{s}} / \varepsilon_{1900^{\circ} \mathrm{C}}: 1.6\end{array}$ & $\begin{array}{c}\alpha_{\mathrm{s}}: 0.694 \\
\rho_{\mathrm{t}}: 0.306 \\
\rho_{\mathrm{s}}: 0.030 \\
\alpha_{\mathrm{s}} / \varepsilon_{2600^{\circ} \mathrm{C}}: 1.3 \\
\alpha_{\mathrm{s}} / \varepsilon_{1900^{\circ} \mathrm{C}}: 1.6\end{array}$ & $\begin{array}{c}\alpha_{s}: 0.526 \\
\rho_{\mathrm{l}}: 0.474 \\
\rho_{\mathrm{s}}: 0.054 \\
\alpha_{s} / \varepsilon_{26000^{\circ} \mathrm{C}}: 1.4 \\
\alpha_{s} / \varepsilon_{1900^{\circ} \mathrm{C}}: 1.8\end{array}$ & $\begin{array}{c}\alpha_{s}: 0.520 \\
\rho_{1}: 0.480 \\
\rho_{s}: 0.058 \\
\alpha_{s} / \varepsilon_{2600^{\circ} \mathrm{C}}: 1.4 \\
\alpha_{s} / \varepsilon_{1900 \mathrm{C}}: 1.9\end{array}$ \\
\hline $\begin{array}{c}0.001 \text { in. } W \text { foil } \\
\mathrm{Al}_{2} \mathrm{O}_{3}(120 \text { grit }), 45 \text { psi, } 2 \text { in. }\end{array}$ & WA9GB & $\begin{array}{c}\alpha_{s}: 0.554 \\
\rho_{1}: 0.446 \\
\rho_{s}: 0.070 \\
\alpha_{s} / \varepsilon_{2600^{\circ} \mathrm{c}}: 1.5 \\
\alpha_{s} / \varepsilon_{1900^{\circ} \mathrm{c}}: 1.9\end{array}$ & $\begin{array}{c}\alpha_{\mathrm{s}}: 0.615 \\
p_{1}: 0.385 \\
\rho_{\mathrm{s}}: 0.061 \\
\alpha_{\mathrm{s}} / \varepsilon_{2600^{\circ} \mathrm{C}}: 1.5 \\
\alpha_{\mathrm{s}} / \varepsilon_{1900^{\circ} \mathrm{C}}: 1.9\end{array}$ & $\begin{array}{c}\alpha_{s}: 0.440 \\
\rho_{1}: 0.560 \\
\rho_{s}: 0.103 \\
\alpha_{s} / \varepsilon_{2600^{\circ} \mathrm{C}}: 1.5 \\
\alpha_{s} / \varepsilon_{1900^{\circ} \mathrm{c}}: 2.0\end{array}$ & $\begin{array}{c}\alpha_{\mathrm{s}}: 0.438 \\
\rho_{\mathrm{t}}: 0.562 \\
\rho_{\mathrm{s}}: 0.110 \\
\alpha_{s} \varepsilon_{2000^{\circ} \mathrm{C}}: 1.5 \\
\alpha_{s} \varepsilon_{1900^{\circ} \mathrm{C}}: 2.0\end{array}$ \\
\hline $\begin{array}{l}\text { WA9GB } \\
\text { and } \\
\text { Pristine } \mathrm{W} \text { screen }\end{array}$ & $\begin{array}{l}\text { WA9GB } \\
\text { and } \\
\text { WS2 }\end{array}$ & $\begin{array}{c}\alpha_{\mathrm{s}}:- \\
\rho_{\mathrm{l}}:- \\
\rho_{\mathrm{b}}:- \\
\alpha_{\mathrm{s}} / \varepsilon_{2600^{\circ} \mathrm{C}:-} \\
\alpha_{\mathrm{s}} / \varepsilon_{1900^{\circ} \mathrm{C}}:-\end{array}$ & $\begin{array}{c}\alpha_{s}: \\
p_{1}:- \\
\rho_{s}:- \\
\alpha_{s} / \varepsilon_{2600^{\circ} \mathrm{C}}:- \\
\alpha_{\mathrm{s}} / \varepsilon_{1900^{\circ} \mathrm{C}}:-\end{array}$ & $\begin{array}{c}\alpha_{\mathrm{s}}: 0.498 \\
\rho_{\mathrm{s}}: 0.502 \\
\rho_{\mathrm{s}}: 0.079 \\
\alpha_{\mathrm{s}} / \varepsilon_{2600^{\circ} \mathrm{C}}: 1.4 \\
\alpha_{\mathrm{s}} / \varepsilon_{1900^{\circ} \mathrm{C}}: 1.8\end{array}$ & $\begin{array}{c}\alpha_{\mathrm{s}}: 0.492 \\
\rho_{\mathrm{s}}: 0.508 \\
\rho_{\mathrm{s}}: 0.082 \\
\alpha_{\mathrm{s}} \varepsilon_{2000 \mathrm{C}}: 1.4 \\
\alpha_{\mathrm{s}} \varepsilon_{1900 \mathrm{CO}}: 1.9\end{array}$ \\
\hline $\begin{array}{c}\text { WA9GB } \\
\text { and } \\
10 \times 10 \text { mesh, } 0.01 \text { in. dia. } W \text { screen } \\
\mathrm{Al}_{2} \mathrm{O}_{3}(120 \text { grit }), 45 \mathrm{psi},<1 \text { in. }\end{array}$ & $\begin{array}{l}\text { WA9GB } \\
\text { and } \\
\text { WSA11G* }\end{array}$ & $\begin{array}{c}\alpha_{\mathrm{s}}: 0.630 \\
\rho_{\mathrm{t}}: 0.370 \\
\rho_{\mathrm{s}}: 0.077 \\
\alpha_{\mathrm{s}} / \varepsilon_{2600^{\circ} \mathrm{C}}: 1.3 \\
\alpha_{\mathrm{s}} / \varepsilon_{1900^{\circ} \mathrm{c}}: 1.6\end{array}$ & $\begin{array}{c}\alpha_{\mathrm{s}}: 0.691 \\
\rho_{\mathrm{s}}: 0.309 \\
\rho_{\mathrm{s}}: 0.050 \\
\alpha_{\mathrm{s}} / \varepsilon_{2600^{\circ} \mathrm{C}}: 1.4 \\
\alpha_{\mathrm{s}} / \varepsilon_{1900^{\circ} \mathrm{C}}: 1.7\end{array}$ & $\begin{array}{c}\alpha_{\mathrm{s}}: 0.522 \\
\rho_{\mathrm{t}}: 0.478 \\
\rho_{\mathrm{s}}: 0.073 \\
\alpha_{\mathrm{s}} \varepsilon_{2000^{\circ} \mathrm{C}}: 1.4 \\
\alpha_{\mathrm{s}} / \varepsilon_{1900^{\circ} \mathrm{C}}: 1.8\end{array}$ & $\begin{array}{c}\alpha_{\mathrm{s}}: 0.512 \\
\rho_{\mathrm{t}}: 0.488 \\
\rho_{\mathrm{s}}: 0.077 \\
\alpha_{\mathrm{s}} / \varepsilon_{2000^{\circ} \mathrm{C}}: 1.4 \\
\alpha_{\mathrm{s}} / \varepsilon_{1900^{\circ} \mathrm{c}}: 1.8\end{array}$ \\
\hline
\end{tabular}

*Pristine data is listed for identically prepared screens (WS2 or WSA10G). 


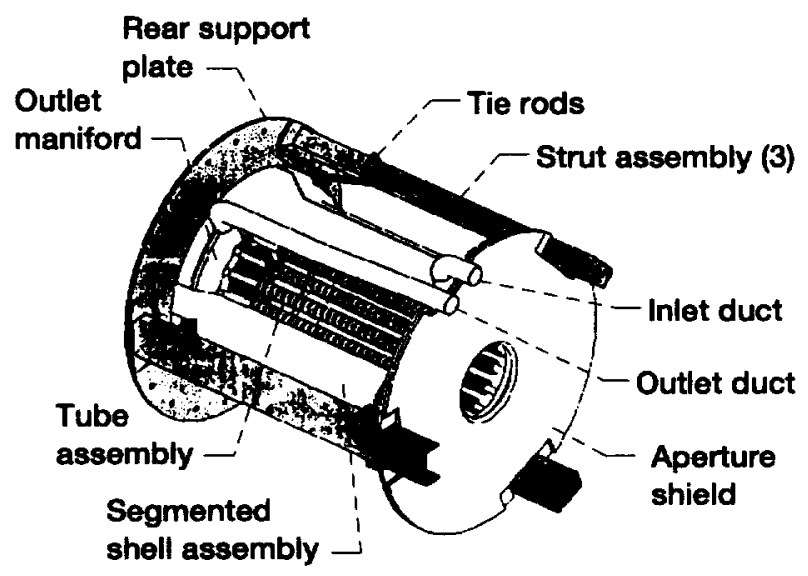

Figure 1.-SDFD heat receiver.

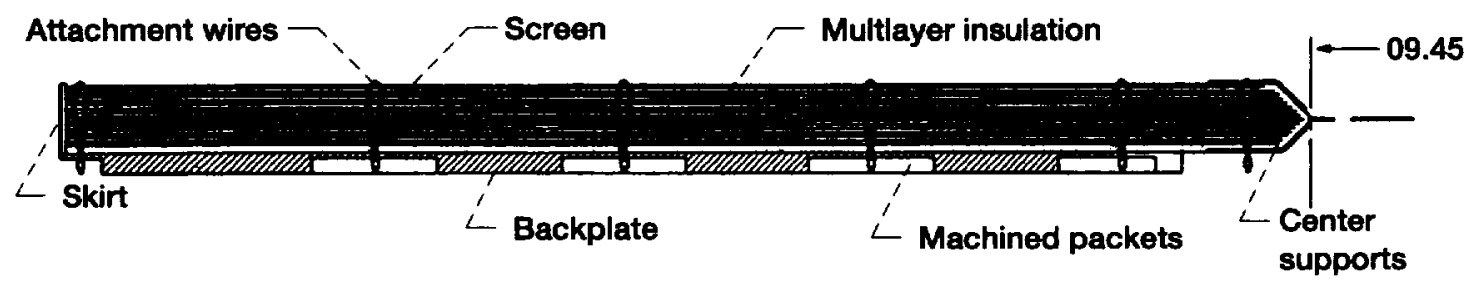

Figure 2.-SDFD Aperture shield cross section.

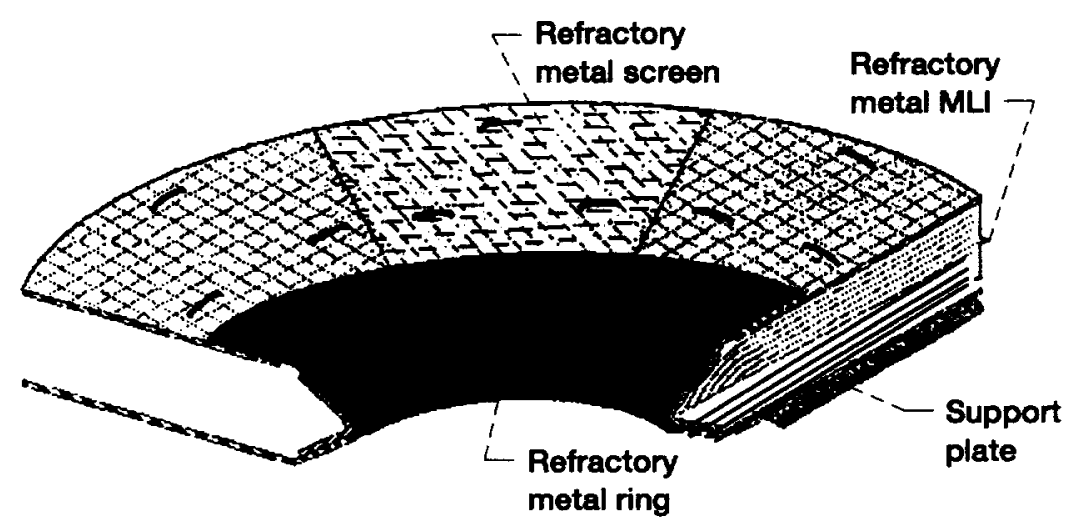

Figure 3.-SDFD Aperture shield section view. 


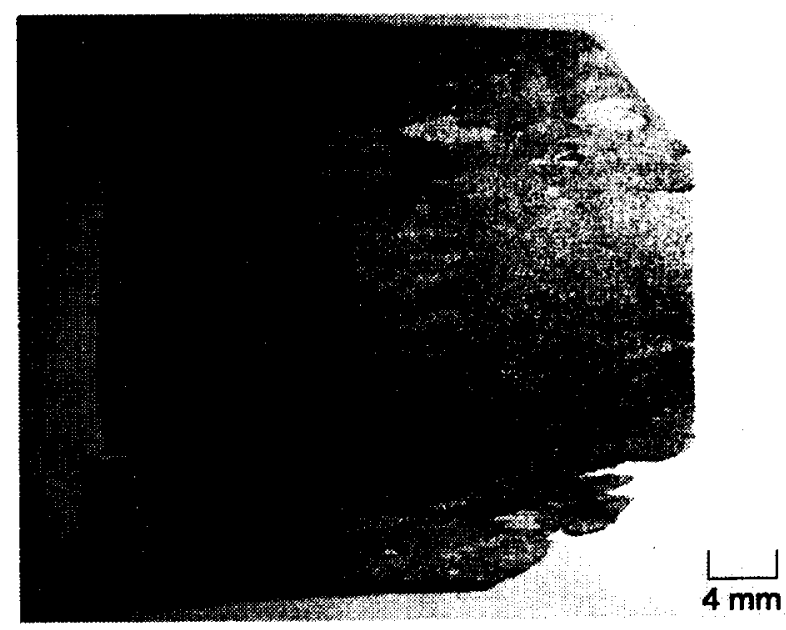

Figure 4.-Grit-blasted $W$ foil (sample WA7GB) after $A O$ and VHT exposures.
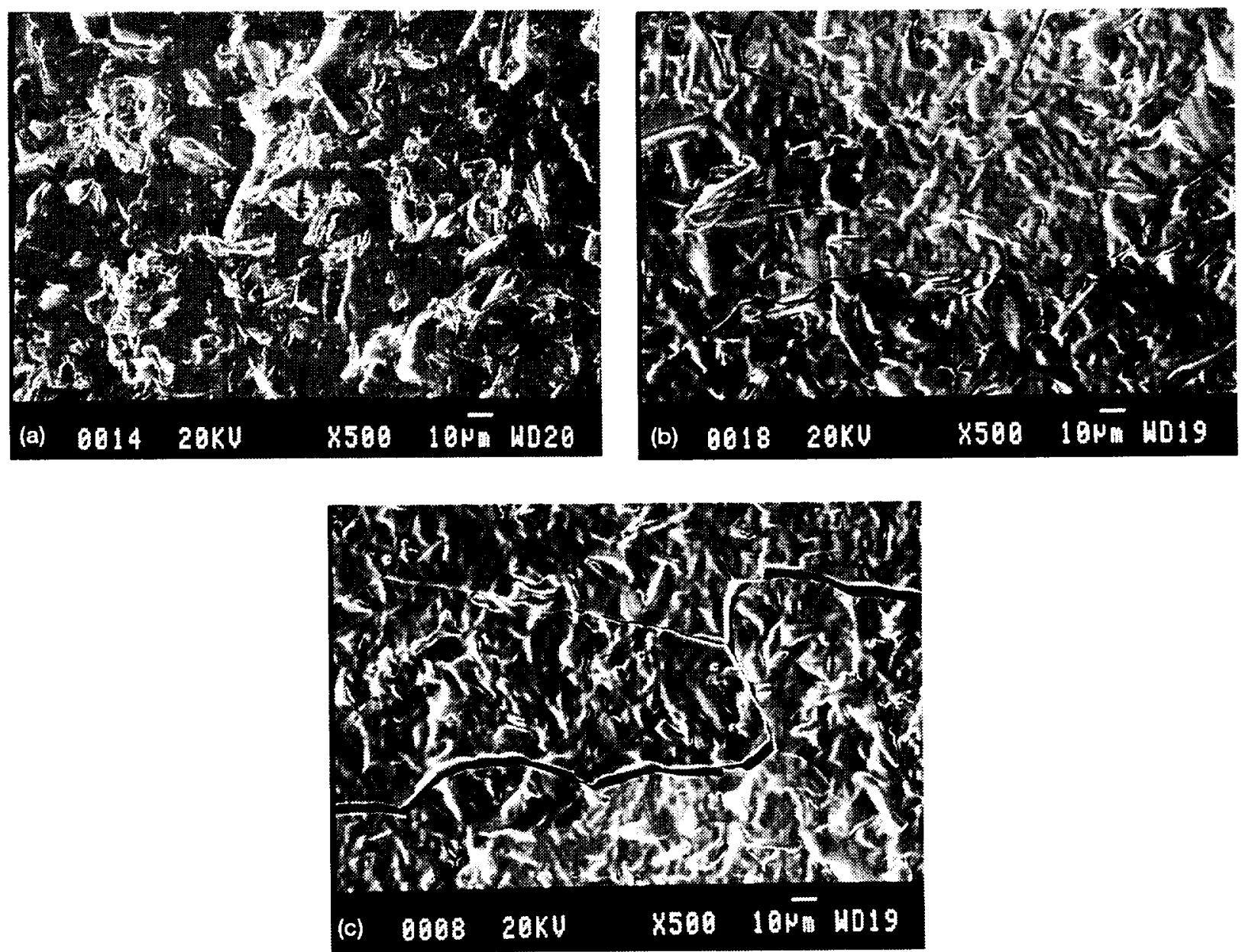

Figure 5.-Pristine and durability tested (AO and VHT) grit-blasted W foil. (a) Pristine sample WA12GB. (b) Sample WA7GB after 1st VHT. (c) Sample WA7GB after 2nd VHT. 

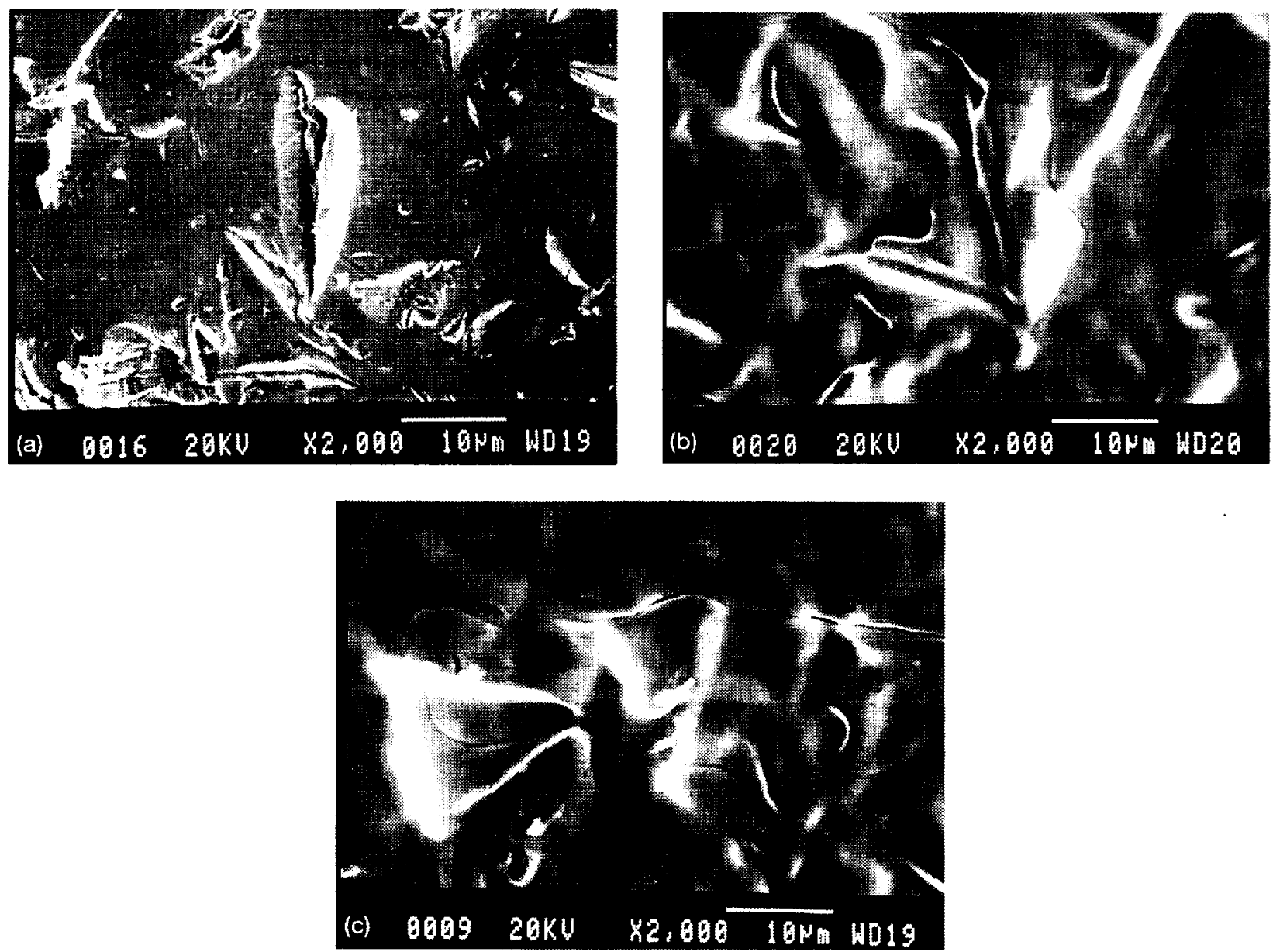

Figure 6. - High magnification of pristine and durability tested (AO and VHT) grit-blasted $W$ foil. (a) Pristine sample WA12GB. (b) Sample WA7GB after 1st VHT. (c) Sample WA7GB after 2nd VHT.

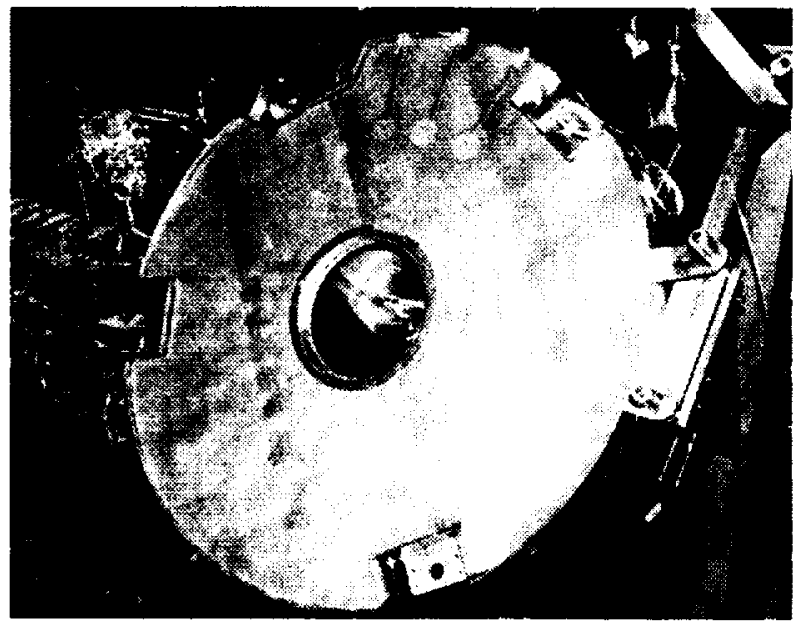

Figure 7.-Aperture shield test article used for thermal shock test. 

Public reporting burden for this collection of information is estimated to average 1 hour per response, including the time for reviewing instructions, searching existing data sources, gathering and maintaining the data needed, and completing and reviewing the collection of information. Send comments regarding this burden estimate or any other aspect of this collection of information, including suggestions for reducing this burden, to Washington Headquerters Services, Directorate for Information Operations and Reports, 1215 Jefferson Davis Highway, Suite 1204, Artington, VA 22202-4302, and to the Office of Menagement and Budget, Paperwork Reduction Project (0704-0188), Weshington, DC 20503.
1. AGENCY USE ONLY (Leave blank) 2. REPORT DATE 3. REPORT TYPE AND DATES COVERED January 1998
Technical Memorandum

4. TITLE AND SUBTITLE 5. FUNDING NUMBERS

Optical Property Enhancement and Durability Evaluation of Heat Receiver Aperture Shield Materials

6. AUTHOR(S)

WU-632-1A-1E-00

Kim K. de Groh, Donald A. Jaworske, and Daniela C. Smith

7. PERFORMING ORGANIZATION NAME(S) AND ADDRESS(ES)

B. PERFORMING ORGANIZATION REPORT NUMBER

National Aeronautics and Space Administration

Lewis Research Center

Cleveland, Ohio 44135-3191

E-11061

9. SPONSORINGMONITORING AGENCY NAME(S) AND ADDRESS(ES)

10. SPONSORINGMONITORING AGENCY REPORT NUMBER

National Aeronautics and Space Administration

Washington, DC 20546-0001

NASA TM-1998-206623

AIAA-98-0270

11. SUPPLEMENTARY NOTES

Prepared for the 36th Aerospace Sciences Meeting \& Exhibit sponsored by the American Institute of Aeronautics and Astronautics, Reno, Nevada, January 12-15, 1998. Kim K. de Groh and Donald A. Jaworske, NASA Lewis Research Center; Daniela C. Smith, Cleveland State University, Cleveland, Ohio 44115. Responsible person, Kim K. de Groh, organization code, 5480 (216) 433-2297.

12a. DISTRIBUTIONIAVAILABILITY STATEMENT 12b. DISTRIBUTION CODE

Unclassified - Unlimited

Subject Categories: 18,20 , and 26

Distribution: Nonstandard

This publication is available from the NASA Center for AeroSpace Information, (301) 621-0390.

13. ABSTRACT (Maximum 200 words)

Under the Solar Dynamic Flight Demonstration (SDFD) program, NASA Lewis Research Center worked with AlliedSignal Aerospace, the heat receiver contractor, on the development, characterization and durability testing of refractory metals to obtain appropriate optical and thermal properties for the SDFD heat receiver aperture shield. Molybdenum and tungsten foils were gritblasted using silicon carbide or alumina grit under various grit-blasting conditions for optical property enhancement. Black rhenium coated tungsten foil was also evaluated. Tungsten, black rhenium-coated tungsten, and grit-blasted tungsten screens of various mesh sizes were placed over the pristine and grit-blasted foils for optical property characterization. Grit-blasting was found to be effective in decreasing the specular reflectance and the absorptance/emittance ratio of the refractory foils. The placement of a screen further enhanced these optical properties, with a grit-blasted screen over a grit-blasted foil producing the best results. Based on the optical property enhancement results, samples were tested for atomic oxygen and vacuum heat treatment durability. Grit-blasted $\left(\mathrm{Al}_{2} \mathrm{O}_{3}\right.$ grit) 2 mil tungsten foil was chosen for the exterior layer of the SDFD heat receiver aperture shield. A 0.007 in. wire diameter, $20 \times 20$ mesh tungsten screen was chosen to cover the tungsten foil. Based on these test results, a heat receiver aperture shield test unit has been built with the screen covered grit-blast tungsten foil exterior layers. The aperture shield was tested and verified the thermal and structural durability of the outer foil layers during an off-pointing period.

\begin{tabular}{|c|c|c|}
\hline \multicolumn{3}{|l|}{ 14. SUBJECT TERMS } \\
\hline \multicolumn{3}{|c|}{$\begin{array}{l}\text { Solar dynamic power systems; Thermal vacuum tests; High temperature tests; } \\
\text { Tungsten; Molybdenum; Durability; Absorptance; Emittance }\end{array}$} \\
\hline $\begin{array}{l}\text { 17. SECURTY CLASSIFICATION } \\
\text { OF REPORT }\end{array}$ & $\begin{array}{l}\text { 18. SECURITY CLASSIFICATION } \\
\text { OF THIS PAGE }\end{array}$ & $\begin{array}{l}\text { 19. SECURITY CLASSIFICATION } \\
\text { OF ABSTRACT }\end{array}$ \\
\hline Unclassified & Unclassified & Unclassified \\
\hline
\end{tabular}

\begin{tabular}{|c|} 
15. NUMBER OF PAGES \\
18 \\
\hline 16. PRICE CODE \\
$\mathrm{AO} 3$ \\
\hline
\end{tabular}

20. LIMITATION OF ABSTRACT 